\title{
INFLUENCE OF CORRUPTION ON THE ECONOMIC DEVELOPMENT OF UKRAINE IN TERMS OF REFORMATION: A RETROSPECTIVE ANALYSIS
}

\author{
Lesia Savchenko', Anatolii Subbot ${ }^{2}$ \\ Kyiv International University, Ukraine \\ Yurii Demianchuk ${ }^{3}$ \\ Bila Tserkva Institute of Economics and Management, \\ Open International University of Human Development "Ukraine", Ukraine
}

\begin{abstract}
The subject of the study is to investigate the causes of the influence of corruption on the economic development of Ukraine in the context of reform. Corruption occurs at all levels of society and in some way interferes in all elements of society, and thus negatively affects democracy and economic development of the country. The research methodology involves a retrospective analysis of the problem of inveteracy of corruption associated with the study of its impact on the economy. It is precisely endemic corruption that threatens the formation of Ukraine's stability and its transition to a market economy. Corruption as one of the most ancient phenomena in society exists in every modern country. The general understanding of corruption is that corruption is detrimental to economic growth. There are also many causes of corruption, namely, a cultural factor, a psychological factor and, therefore, factors associated with the system can cause corruption in every society. The methodological basis for the research was the works of Tylchyk O.V., Bilous V.T., Subbot A.I., Lytvynenko V.I., Hvozdetskyi V.D., Popovych V.M., Bodnarchuk O.H. in the field of administrative law and issues of counteracting and combating corruption, which indicate that there are some factors, such as monopoly power, discretionary power, and low civil servants' liability, that may provide opportunities for the development of corruption. The purpose of the article was to analyse the causes of the impact of corruption on the country's economic and political development. Today, corruption has a wide range of activities that undermine the country's development. Researchers argue that corruption affects the country's economic growth. However, contradictory evidence was found that corruption can have a positive effect on the country's economic development or have no significant impact on economic performance. On the basis of analysis of these works, it was established that corruption is the result of institutional weakness, with a potential adverse effect on the country's economic efficiency. Corruption negatively affects the efficiency of public spending, reduces budget revenues and increases its deficit, impedes foreign direct investment, reduces the effectiveness of international assistance, and hinders economic development. As a result of the analysis, ways to reduce corruption are identified, which suggest a policy of reducing corruption in Ukraine. The result of the study was conclusions on the need to develop and form a coherent system of scientific and legal views on identifying effective anticorruption measures, optimizing and improving the effectiveness of anticorruption activities, with the involvement of international experience in coordinating and minimizing information leakage and engaging civic initiatives among the non-public sector.
\end{abstract}

Key words: corruption, economic crime, fraud, economy, economic development.

JEL Classification: K1, K14, K15, K42

\footnotetext{
Corresponding author:

${ }^{1}$ Kyiv International University.

E-mail: YDemyanchuk@gmail.com

${ }^{2}$ Department of Public-Law Disciplines, Kyiv International University.

E-mail: YDemyanchuk@gmail.com

${ }^{3}$ Department of Law, Bila Tserkva Institute of Economics and Management,

Open International University of Human Development "Ukraine”.

E-mail: YDemyanchuk@gmail.com
} 


\section{Introduction}

Today, Ukraine has implemented a number of important reforms that help to overcome corruption, in particular, in the areas of energy, finance, and economics. However, judicial reform continues to lag behind.

The relevance of the study is that the combination of rampant corruption and market instability, political instability in Ukraine are the main obstacles to the development of the economy in the country. Anticorruption Ukrainian laws have an impact on corruption conduct both in private and public sectors. The Law on Prevention of Corruption has measures to monitor the implementation of anticorruption provisions. However, the weak judicial system limits the implementation of anticorruption laws of Ukraine. Thus, the imperfection of the legislative framework results in the rapid growth of corruption and economic crime in Ukraine, preventing the state from becoming a fully-fledged, prosperous, democratic country capable of responding effectively to violations of its own sovereignty.

Current research on preventing and combating corruption is aimed at developing relevant, effective means to overcome this phenomenon. However, we are aware that without identifying the causes of the emergence and entrenchment of this phenomenon in the structure of the state, it is impossible to work effectively in overcoming the corruption phenomena that penetrate all socio-economic sectors.

Over the past few years, scientists' opinions have been divided into determining the factors influencing the country's economic development and the role of corruption in this process. Theorists argue that economic development is the result of exogenous factors that affect the economy, for example, the level of technical progress. Proponents of another point of view believe that economic development is primarily a result of domestic processes in the country. However, both the first and the second ones point to the development of corruption and the emergence of new corruption components in the country's development processes. The main reasons for writing an article are the lack of a direct answer to the question of the dependence of these phenomena. In our opinion, the answer can be found in the history of the rooting of the phenomenon of corruption on the grounds of the formation and strengthening of the democratic nature of the state.

Therefore, the novelty of the research is to find out reasons for the rooting of corruption components on the basis of a retrospective analysis of Ukraine's development. The author tries to find out reasons for the sustainability of economic crime and corruption in Ukraine on the basis of a historical analysis of events from the break with the Soviet system to date, which determines the novelty of the proposed review. The result of this review is the formulation of proposals based on a retrospective analysis of causes of the sustainability of corruption and economic crime regarding the further reformation of Ukraine under the conditions of support for civil society and the international community.

\section{Economic crime and corruption}

Economic crime is usually identified with another term - corruption. There are different definitions of corruption. Each definition highlights various dimensions of a particular phenomenon. However, we share the opinion of Melnyk M.I. and Hvozdetskyi V.D. in the context of the lack of a clear and unambiguous idea about the definition of corruption (Melnyk, 2002; Hvozdetskyi, 2013).

In the scientific environment, corruption is defined as: 1) abuse of public authority by public officials, political and civil servants, in order to illegally enrich themselves or their subordinates (National Integrity Systems, 1997); 2 ) activities of state authorized persons aimed at the abuse of powers and positions and the related opportunities provided to them for obtaining from natural and legal persons material goods, services, advantages, benefits or other tangible or intangible effects, as well as bribery of officials by natural and legal persons (Tereshchuk, 2000);

3 ) the bribery of public servants on the part of legal entities and individuals who encroach on normatively established social relations in the field of public service (Ponomarev, 1993);

4) the use by an official of public authorities and management of his official position for personal enrichment (Kabanov, 1995);

5) abuse by management entities of their powers to meet personal or group interests (Mishin, 1991);

6) a social phenomenon that encompasses the whole set of corruption acts related to the unlawful use by persons authorized to perform state functions of the power given to them, official authority, appropriate possibilities for the satisfaction of personal interests or interests of third parties, as well as other corruption offenses, including those that create conditions for committing corrupt acts, or conceal or connive them (Melnyk, 2002).

From the above, we can distinguish three groups of definitions concerning the complex definition of the concept of corruption. The first group of definitions refers to public ethics. In this case, corruption is defined as the ethical mutual division of interests between public and private space. The second group of definitions relates to corruption issues with regard to transparency by the state. However, there is the third group of definitions that we propose as basic: corruption is one of many parts of a more complex criminal phenomenon, which is an economic crime.

In the context of the abovementioned, Bodnarchuk O.H. notes that the modern interpretation by the legislator of the "corruption" concept does 
not contribute to an effective counteraction to its manifestations in the realm of public power. In addition, it is impossible to give a clear, unambiguous, comprehensive legislative definition for the day. In this regard, Bodnarchuk O.H. believes that the concept of "corruption" should be determined on the doctrinal rather than legislative level since it gives a generalized view of corruption as consisting of different in nature but identical in essence acts, which are not reduced to any particular type of offense and manifested in a variety of forms and entail criminal, administrative, disciplinary, civil liability. In addition, based on the experience of foreign countries, the lack of a legal concept of corruption is not a significant obstacle to the introduction of effective means of counteracting this phenomenon (Bodnarchuk, 2016).

Since the practice and research of modern legal science in relation to the conceptual and categorical foundations of the phenomenon of corruption gives rise to the conclusion that there is no complete and meaningful definition of the "corruption" concept, therefore, our vision is not limited to crimes committed in the public sector, but also extends to those carried out by private sector entities.

Investigating the relation between the concepts of "corruption" and "economic crimes" Tylchyk O.V. emphasizes that the shadow economy generates corruption, and the latter, in turn, creates the basis for the prosperity of the shadow economy. The cause and effect, the purpose and the means are so interrelated and interconnected that form a closed circle (PiasetskaUstych, 2016; Tylchyk, 2015).

Thus, economic crime covers a wide range of offenses, from financial crimes committed by banks, evasion of taxes, illegal capital, money laundering, crimes committed by public officials (bribery, theft), etc.

It is believed that economic crime causes significant social damage. This is because it affects not only democratic institutions but also undermines state property by reducing available resources for the implementation of state policy. At the same time, the social damage caused by such criminal activity is usually invisible: in addition to general indignation, it is difficult to have a precise understanding of the real consequences of these crimes (Hvozdetskyi, 2013; Tylchyk, 2015).

Moreover, selective and ineffective prosecution of economic crimes and responsible persons is evidence of structural impunity in our judicial system. Of course, this is related to the fact that economic crimes are often provoked by powerful actors associated with political and economic power.

Economic crime stems from hidden power, which defines relationships between the economy and politics. Market reforms implemented in Ukraine over the past decades have led to a gradual process of borrowing major economic groups. Now, this enthusiasm is expressed in the powerful influence of economic actors in the decision-making process, the implementation of state policy, and the distribution of economic and social resources.

\section{Reasons for the rooting of economic crimes}

In order to put an end to this situation, Ukraine had to create its own legal rules and institutions. In the first years of Ukraine's independence, economic crime and corruption did not prevent laws that could solve them. According to Tylchyk O.V., in this period, shadow activity was considered to be outside the planned state economy, which embodied the laws of the administrative-command control system and was recognized as unlawful, mainly criminal. The above statements are superficial because, despite the real economic activity outside the planned economy, which was determined by the criminal, certain types of crimes (for example, corruption) were identified with the shadowing of the economy (Tylchyk, 2015).

A retrospective analysis of the period shows that in the late 1990s, with the alleged further privatization, Ukrainian development was deepened without adequate legal safeguards and the adoption of legal norms. Resources continued to end up in the hands of the elite as a result of high-level corruption, leaving the overwhelming majority of citizens impoverished and without faith in the Ukrainian state.

Recent World Bank reviews of citizens' perceptions of state integrity show that citizens have little confidence in government institutions. Ukrainians believe that their country has a more serious problem of corruption than other countries (World Bank, 2006). Economic crime is a serious problem in Ukraine.

Thus, the capture of the privatization process by economic crime and corrupt officials has led to a sharply polarized society. Instead of the emergence of a powerful middle class, Ukraine now has an extremely rich new elite and a depleted population.

Speaking about the factors influencing the historical periodization of the development of cognitive activity of the shadow economy and shadowing in our country, Tylchyk O.V. notes the following: in relation to the peculiarities of the country's historical development, its membership in post-Soviet countries, such studies were conducted within the limits of the universally established doctrine for all the countries of the Soviet Union, and therefore they have their features in comparison with those, which have been carried out in other countries of the world; are carried out with considerable delay compared with the researches of western specialists and are based on Western concepts and theories, which sometimes leads to errors during the translation, the introduction of new terms and concepts into the national science without taking into account the peculiarities of domestic doctrinal positions and modern realities (Tylchyk, 2015). 
Thus, the shadow economy and endemic corruption of the previous period are turning into modern problems of economic crime and corruption. Their metamorphosis is formed by a variety of political, economic, geographical, and cultural factors, a common heritage of the transitional period.

In this article, we argue that the legacy of the postSoviet period and the deliberate political decisions of the Ukrainian government were not the main factors of the existing economic crime problems. Ukraine failed to adopt the necessary legal infrastructure to combat economic crime and corruption.

The political costs of economic crime for Ukraine are impressive. The widespread corruption and penetration of economic crime into the political process hamper the development of new laws necessary for the development of a free democratic market economy. Citizens have lost faith in the integrity and capacity of the legal process. Very damaged tax authority and relations of officials with economic criminal schemes deprive the state of the necessary income. Lack of resources due to their inability to levy taxes and large losses of income through illegal and insider privatization, Ukraine cannot fulfil its obligations to citizens in providing decent wages, benefits, and medical care.

On the basis of the above, we can state that the diversity of contemporary economic crime in Ukraine is also explained by contacts with international corruption and the traditional factors contributing to the increase of economic crime. As a rule, the growth of economic crime against corruption is a transient phenomenon for countries in the period of establishment, a reaction of the system to the absence of legal norms during a period of profound redistribution of influence. According to this view, economic crime and corruption will become much less threatening when legal rules will be adopted to meet a market economy.

Economic crime in Ukraine is a rather differentiated phenomenon. Significant regional differences within Ukraine are explained by geography, political structure, and historical heritage. The porosity of the borders of Ukraine determined its transit functions for drug trafficking from the countries of Southwest Asia (Iran and Afghanistan) and Central Asia (Kyrgyzstan and Tajikistan), as well as the Caucasus (Chechnya, Georgia, and Azerbaijan), destined for Eastern Europe (mainly Hungary) and Western Europe. Economic crimes in the central part of Ukraine are closely linked to construction, real estate, banking activities, and abuses dependent on international air connections (Walter Kurtz, Sober Look, 2014).

Taking into account the power and relevance of the issue under investigation, as well as the current diversification of criminal economic schemes, the prevalence of corruption indicates that this phenomenon will not quickly disappear. Existing contacts of economic criminals and their international partners will contribute to the growth and complication of economic crime schemes. This applies in particular to more complex financial transactions related to money laundering abroad. The situation of counteraction to such phenomena is complicated by the fact that Ukraine cannot separate criminal economic activity from neighbouring states. Economic criminals and their organizations adapt to countries and develop together with the states. Control of the domestic crime problem in Ukraine is only partly under its control.

\section{Retrospective analysis of causes of economic crime}

In the article, the author tries to trace the causes, factors, and conditions that contributed to the development of economic crime against the backdrop of corruption. It is clear that these phenomena arose long ago as one of the oldest and most promising phenomena of human society, corruption and economic crime exist in all countries of the modern world, and this is not only a problem of countries in a state of development. The classic concept of corruption as a negative phenomenon of general politics was proclaimed during the times of antiquity by Plato and Aristotle. In his theory, Plato considered democracy, oligarchy, and tyranny as regimes protecting the interests of rulers. This classic concept of corruption continues in our time and is central to the political thought of Machiavelli, Montesquieu, and Rousseau. For Machiavelli, corruption was a process, by which the integrity of citizens was undermined and eventually ruined. Montesquieu considered corruption as a dysfunctional process that transformed the political order into a monarchy and despotism. According to Rousseau, political corruption is a necessary consequence of the struggle for power. He argued that it is the political system that destroys a person and gives rise to its corruptibility (Tylchyk O.V., Bilous V.T., Subbot A.I., Lytvynenko V.I., Hvozdetskyi V.D., Popovych V.M., Bodnarchuk O.H.).

However, in the proposed review, we will confine our analysis to the post-Soviet and modern periods.

In particular, Tylchyk O.V. characterizes the transitional post-Soviet period with the growth of the shadow economy in relation to the existence of risks of the transition period (privatization, denationalization, the transition from the command and administrative system of governance to democratic one). A significant accumulation of administrative and legal rules, in particular, in the form of concepts and strategies of state regulation in various spheres of the economy, reforming the system of subjects of economic management and, respectively, adopting in a short time a large number of statutory legal acts regulating their administrative and legal status, which was accompanied by duplication of powers of various subjects in this area. Accumulation of statutory legal acts regulating the issues of combating 
crime, which marked the high development of the so-called "economic crime" or "crime in the economy", which acquire characteristics of organized crime (Tylchyk, 2015).

In the context of the above, we can state that the post-Soviet heritage can be one of the most important factors, which explains the current distribution of economic crime and corruption in Ukraine. The established hereditary schemes are perhaps much more complicated than the established shadow economy or authoritarian tradition without respect for the rule of law: the deliberate social policy aimed at controlling internal immigration, the development of the apparatus of social control and conscious government decisions of the last years of the post-Soviet period, all this contributed to the rooting of modern economicallycriminal structures.

The biggest element of the post-Soviet period is corruption and the shadow economy. The shadow economy has not diminished since 1991, but now its influence is estimated at more than sixty percent of the economy. During the Soviet era, members of the shadow economy who worked throughout the former USSR regularly bribed officials to ensure the effectiveness of economic schemes, and law enforcement officers became participants in corruption schemes to stop prosecutions. In Ukraine, there was no lustration or detention of civil servants. Consequently, the modern state was inherited by the same corrupt government officials.

To date, these state officials enjoy an even more economically privileged position, since the property is redistributed without anticorruption laws, senior government officials of national and regional bodies receive significant material benefits from economic crime schemes. Large cities were centres of a common shadow economy. Citizens had more or less stable material security, and officials received unjustified benefits from corruption. For this reason, the problems of economic crime were particularly acute in Kyiv, Donetsk, Dnipropetrovsk, etc. The criminals who were detained for economic violations at that time reappeared as key contributors to the current corruption economy (Williams, 2004).

Previous and current security officials play an important role in the economic crime. The presence of former security representatives in commercial enterprises contributes to their current activities. The existing banking sector in Ukraine uses many years of experience in special services that worked secretly and covered large illegal transactions.

Modern analysts V.A. Predborskyi, R.S. Demidov, O.V. Kostin, V.T. Bilous and V.M. Popovych believe that economic crime arose practically spontaneously as a result of the collapse of the former USSR. However, it is obvious that the economic-political connection is an alliance of the former party elite, members of the apparatus of law enforcement and security, as well as groups of economic criminals who together encompassed the legal and illegal sectors of the economy. As we consider, this becomes the most destructive element of economic crime in Ukraine. The criminalization of the banking sector and the privatization process became the main obstacles to the development of a free market and a fair distribution of property.

The degree of these problems distinguishes economic crime and corruption in Ukraine from other countries with the high crime rate. Economic crime connected with the banking and financial markets destabilizes the country more than the more traditional elements of organized crime.

Corruption and economic crime cannot be simply differentiated. A large part of the committed economic crime combines access to information or goods and services of civil servants who are under the influence of corrupt schemes or the threat of the use of force.

In this context, Bodnarchuk O.H. stresses that the system of measures to counteract corruption and economic crimes should be aimed at increasing the complexity of the implementation of corruption offenses; restraining the risk of committing them; reducing the benefits of their commitment (Bodnarchuk, 2016).

We believe that such an approach will contribute to the destruction of criminal-economic relation in Ukraine, which has a significant impact on the electoral and legislative processes by sponsoring candidates for parliament and by pressure on individuals in legislative authorities to ensure a policy that protects their interests. Given that the criminalization of legislative bodies is a problem both at the national and regional levels.

There is also the suggestion that this connection penetrates the highest levels of government in administrative sectors. The banking and oil and gas industries are the most backed up in this regard. Employees in Ukraine are helping their partners in the shadow economy, with whom they are inextricably linked by complex financial relations. Sometimes this assistance is not financial but protects them from the application of the criminal law. This connection is common since the criminal world has established informal contacts with politicians.

The current legislative process in Ukraine partially destroys political and economic ties, which is particularly noticeable in the current transitional period, when the Rada and regional legislative bodies must adopt legal limits for the development and regulation of a market economy. Corruption in legislative bodies hampered adoption of necessary laws. Members of the legislature, who personally use the transfer of property from the state to private use, impede the adoption of laws on the regulation of the economy or the limitation of money laundering, and laws that may lead to their prosecution. As noted in the studies by Demianchuk Yu.V., this contributed to the provision of immunity to members 
of the parliament, which intensified the criminalization of Ukrainian legislation. Members of the Ukrainian parliament also oppose the establishment of conflicts of interest laws (Demianchuk, 2016).

The criminalization of legislative authorities is a serious problem. In particular, this thesis is confirmed by research by Demianchuk Yu. V. The impunity of civil servants raises the issue among citizens regarding the integrity of the legislative process. The cynicism of the election process is that parliamentary elections often allow members of the parliament to quickly earn money.

The institutional capacity to consider political and economic ties in Ukraine is rather limited. Unfortunately, Ukraine has no effective professional and institutional resources to overcome economic crime and corruption. Differences between parliament and presidential administration create additional obstacles to mobilizing such measures. But the biggest obstacle is the lack of political will to solve these issues (Melnyk).

Concluding a retrospective review of the causes of corruption and economic crime, we can say that Ukraine has become an independent state without any practical experience in counteracting economic crime and corruption, and now it is slowly increasing capabilities for solving it. So far, Ukraine has no effective law enforcement authorities and judicial system, sufficiently independent to block the impact of economic crime. The state has the limited institutional potential for advanced training of existing judges and prosecutors. With limited financial resources, the state can do little to train personnel to meet new requirements or prevent the spread of corruption. The deficit appears over the lack of not only the necessary criminal laws and procedures but also the civil legislation on markets, banking, and commercial transactions. Effective tax policy is absent; therefore, corruption support for economic crime is more advantageous and convenient than cooperation with tax authorities.

An analysis of the theoretical achievements of the implementation mechanisms necessary to support public functions has shown their ineffectiveness. In Ukraine, law enforcement agencies cannot use the methods that are necessary for penetration into a criminal economic organization. Even when enforcement mechanisms are present, corrupt law enforcement officials oppose criminals. Distribution of functions between different branches of law-enforcement activity hinders the investigation.

\section{Conclusions}

Retrospective analysis of the impact of corruption on Ukraine's economic development under conditions of reform, analysis of conceptual and theoretical problems of ensuring the overcoming of corruption and economic crime showed the need to develop and form a holistic system of scientific and legal views on identifying effective measures to counteract such phenomena, optimizing and improving the effectiveness of anticorruption activities.

In particular, it was found that criminal-economic associations or groupings are the engine of systemic corruption. To solve this problem, international experience proposes to introduce impact forces that will facilitate the coordination and minimization of information leakage to criminal groups. Such reforms can help the police to conduct investigations necessary to solve the problems of illicit trade. It is necessary to attract international cooperation for the return of illegal funds, which settled in the banks of Europe and the United States. Turning to the issue of economic crime and corruption, citizens must mobilize to force legislators and the government to develop the necessary solutions.

As a result of the study of this problem, it has to be noted that Ukraine has no knowledge of overcoming economic crime and financial resources to support public initiatives in the non-public sector.

However, with political will, Ukraine can try to solve the problem of domestic economic crime and corruption. Ukrainian nationalism may not be strong enough to counteract the debilitating effects of a criminalized economy and widespread corruption. But, without sufficient independent media and nongovernmental organizations, society cannot create an effective anticorruption movement. If the situation does not change, there will be the unhindered growth of economic crime in the coming decades. Just as society in the past helped to perpetuate control over the Soviet state, the current passivity to growing power and the consolidation of economic crime and corruption could lead to a new form of authoritarianism as a reaction to such abuses.

The ability of Ukraine to remain a functioning sovereign state may in future threaten the serious consequences of economic crime and corruption.

\section{References:}

Bilous V. (2002). Coordination of the fight against economic crime, monograph - Irpin, National Academy of SBGS of Ukraine, 449 p.

Bodnarchuk O. (2016). Theoretical foundations and administrative and legal mechanisms of counteraction to corruption in the State Criminal Execution Service of Ukraine, monograph - Kyiv, "Tsentr Uchbovoi Literatury", $462 \mathrm{p}$.

Hvozdetskyi V. (2013). Administrative-legal and organizational principles of prevention and counteraction of corruption in Ukraine, extended thesis abstract for Dr. Sc. (Jurisprudence). - Kyiv, 36 p.

Demianchuk Yu. (2016). Modern administrative and legal means of prevention and counteraction of corruption in the system of civil service of Ukraine - Kyiv, Law and Innovations, № 4, pp. 92-97. 
Demidov R.-N. (2002). The shadow economy (criminological analysis), thesis for Cand. Sc. (Jurisprudence). SPB, $191 \mathrm{p}$.

Kabanov P. (1995). Corruption and bribery in Russia - Nizhnekamsk, PPC “Guzel”, 172 p.

Kostin A. (2011). Experience in measuring the shadow economy in Western literature. Bulletin of Novosibirsk State University, Vol. 11, pp. 33-43.

Lytvynenko V. (2015). The concept of administrative and legal support for combating corruption in Ukraine, thesis for Dr. Sc. (Jurisprudence). - Kyiv, 400 p.

Melnyk M. (2002). Criminological and criminal legal problems of combating corruption, thesis for Dr. Sc. (Jurisprudence) 12.00.08. - Kyiv, pp. 73-100.

Mishin G. (1991). Corruption: concept, essence, restriction measures, lecture. - M., Academy of MIA RF, 34 p.

National Integrity Systems (1997), textbook ed. by J. Pope. - Berlin, Transparency International, 114 p.

Piasetska-Ustych S. (2016). Corruption and the shadow economy in the system of socio-economic relations of society. Global and National Problems of Economics. - Mykolaiv, V.O. Sukhomlynskyi National University of Mykolaiv, Iss. 10, $34 \mathrm{p}$.

Ponomarev P. (1993). The concept of corruption and criminal law means of its content. Legal and organizational problems of fighting corruption. - M., pp. 47-60.

Popovych V. (2016). Terminology on problems of shadowing and unshadowing of social relations: etymological, praxeological, and methodological foundations of the formation. - Kyiv, Nauka I Pravoohorona, Iss. 4, pp. 138-145. Predborskyi V. (2005). Unshadowing of the economy in the context of transformation processes. Issues of theory and methodology, monograph. - Kyiv, Kondor, 614 p.

World Bank (2006). Corporate Governance, Report on the Observance of Standards and Codes.

Subbot A. (2014). Public participation in the prevention and counteraction of corruption. - Kyiv, Bulletin of National Prosecution Academy of Ukraine, № 4, pp. 56-62.

Tereshchuk O. (2000). Administrative liability for corruption offenses, extended thesis abstract for Cand. Sc. (Jurisprudence) 12.00.08. - Odesa, $20 \mathrm{p}$.

Tylchyk O. (2015). Reform of Ukraine's tax system: modern challenges and benchmarks, monograph, edited by P.V. Pashko, L.L. Taranhul. - Irpin, SRC TP NUSFSU, 570 p.

Walter K., Sober L. (2014). Ukraine Is On The Brink of Total Economic Collapse, Business Insider. 